\title{
Establishment and Characterization of a Cell Line from the Mosquito Anopheles albimanus (Diptera: Culicidae)
}

\author{
Felio J Bello ${ }^{+}$, Helena Brochero, Jorge Boshell*, Victor Olano*, Gloria Rey*
}

Departamento de Biología y Química, Universidad De La Salle, Carrera 2 No. 10-70, Santafé de Bogotá, D.C.
Colombia *Instituto Nacional de Salud, Laboratorios de Virología y Entomología, Apartado Aéreo 80080,
Santafé de Bogotá, D.C. Colombia

A new cell line designated LSB-AA695BB, was established from embryos of the mosquito Anopheles albimanus. The primary culture was initiated in April, 1995, and the first passage was made 48 days later. Serial subcultures of the cells have been carried through 90 passages from Abril 1995 to February 1996. The cells were grown at $28^{\circ} \mathrm{C}$ in MK/VP12 medium, supplemented with $20 \%$ fetal bovine serum; the $\mathrm{pH}$ tolerance ranged between 6.8 to 7.0. The cells have also been adapted to MM/VP12 medium under the same $\mathrm{pH}$, temperature and serum concentration. The majority of the cells were a fibroblasttype. Isozyme characterization showed a pattern similar to that of An. albimanus pupae and adults but distinct from Ae. taeniorhynchus and Ae. albopictus (C6/36) mosquito cell lines. The culture was shown to be free of mycoplasma, bacteria and fungi. Microsporidia contamination of transovarial transmission was controlled with $6.0 \mathrm{mg} / \mathrm{ml}$ of albendazole.

Key words: cell line - karyotype - isozyme patterns - microsporidia

The mosquito Anopheles albimanus Wiedemann is a major vector of human malaria in tropical America. Cell line are currently available for two Anopheles species: An. stephensi liston (Schneider 1969, Pudney \& Varma 1971) and An. gambiae Giles (Marhoul \& Pudney 1972). Insect cell cultures are useful for fundamental studies of cell physiology, genetics and biochemistry; they are also useful as a substrate to isolate and to identify arboviruses and to study parasites (Vaughn 1976, Buckley 1976, Hink 1980, Maramorosch 1980, 1987, Mitsuahashi 1981, 1983, Grace 1982). In 1995, Bello et al. reported primary cell cultures of An. albimanus and described their most significant characteristics, but these cells could not be serially subcultured. This report describes the establishment of a new continuous line of $A n$. albimanus cells and some of its characteristics.

\section{MATERIALS AND METHODS}

Primary cell cultures - Embryonated eggs were collected using the procedure described before by Bello et al. (1995). The incubation time for these eggs was $28 \mathrm{hr}$. Sterilization of the eggs was done with a $1.6 \%$ sodium hypochlorite solution and with

Work supported by COLCIENCIAS and La Salle University as well as Colombian National Institute of Health. ${ }^{+}$Corresponding author. Fax: +57-1-286.8391

Received 23 April 1996

Accepted 17 July 1996
$70 \%$ ethanol; during inmersion of the eggs, each of the substances was stirred continuously for 10 min. After washing the eggs three times with destilled sterile water, they were rinsed with the MK/VP12 medium (Pudney \& Varma 1971). Finally, $1 \mathrm{ml}$ of egg mass was placed into a $2 \mathrm{ml}$ Ten Broek homogenizer where the eggs were broken mechanically. The resultant suspension was placed in a $25 \mathrm{~cm}^{2}$ plastic tissue culture flask containing 5 $\mathrm{ml}$ of the growth medium. The cells were maintained in an incubator at $28^{\circ} \mathrm{C}$.

Medium - The cell culture was initiated and grown in the MK/VP12 medium, supplemented with $20 \%$ fetal bovine serum (FBS) and a mixture of penicillin (100 units $/ \mathrm{ml})$ and streptomicin (100 units $/ \mathrm{ml})$. Albendazole was used to control microsporidian infections in the embryonic cell explants and also to eliminate the parasite with prolonged treatment through several subcultures. Albendazole (Sigma) was dissolved in dimethyl sulfoxide (DMSO, $2.5 \mathrm{mg} / 100 \mathrm{ml}$ ) and added to the medium, three different concentrations were made: $9.0 \mathrm{mg} / \mathrm{ml}, 6.0 \mathrm{mg} / \mathrm{ml}$ and $3.0 \mathrm{mg} / \mathrm{ml}$. The medium was sterilized by passage through a $0.22-\mathrm{mm}$ millipore filter. After the initial cell growth, the culture medium containing albendazole was changed every two days. Infected cell cultures were exposed to the drug for 60 days. After albendazole treatment, medium containing the drug was replaced by drug-free medium, containing all other supplements (FBS, antibiotics) (Haque et al. 1993) 
Subcultures - The first successful subculture was obtained in April of 1995; since that time, the cells have been maintained for over 90 passages. When confluency was reached, the cell monolayer was scraped with a rubber policeman and the cells were dispersed by gentle pipetting. The first subcultures were developed at a split ratio of $1: 2$ at an interval of 7 days, however the split ratio was increased gradually up to $1: 10$ and subcultures were made every 5-6 days. The cells were transferred to $25 \mathrm{~cm}^{2}$ flasks, which contained $5 \mathrm{ml}$ of fresh culture medium. The incubation temperature was $28^{\circ} \mathrm{C}$ and daily observations were performed using an inverted Olympus CK-2 microscope.

Morphological characteristics - Cell morphology was observed and photographed using an inverted microscope with phase contrast and a "Leitz" microphotographic system in increments of 100 to 400X magnification.

Cytogenetic characteristics - Chromosomes were prepared according to the Schneider (1987) technique, with some modifications. Cell exposition time to colchicine solution was $3 \mathrm{hr}$. For the C-banding softening, four day maturation blank sheets were used; these sheets were submerged in $0.2 \mathrm{~N}$ hydrocloric acid for $50 \mathrm{~min}$. After washing with tap water the sample were placed in $5 \%$ $\mathrm{Ba}(\mathrm{OH})_{2}$ for $1 \mathrm{~min}$ at $53^{\circ} \mathrm{C}$, and finally incubated at $54{ }^{\circ} \mathrm{C}$ in a double citrate solution (2XSSC) for 1 $\mathrm{hr}$. Staining was done with a $2 \%$ Giemsa solution (Motara \& Rai 1977, Marchi et al. 1980).

Analyses of isozyme patterns - Isozymatic phenotypes from four systems were examined; phosphoglucose isomerase (PGI-5.3.1.9), phosphoglucomutase (PGM-2.7.5.1), mannose phosphate isomerase (MPI-5.3.1.8) and phosphogluconate dehydrogenase (6-PGDH-1.1.1.4.4). Isozymes were resolved by electrophoresis technique on cellulose acetate, following the procedures described by Brown and Knudson (1980). Cell samples were simultaneously electrophoresed with adult and pupae extracts from An. albimanus. The isozyme patterns of our cell line were compared with that of the C6/36 clone of Ae. albopictus (Igarashi 1978) and with a culture of Ae. taeniorhynchus (Bello et al. 1995). All samples were treated with their own cell buffer, that corresponded to each system. Later the cells were frozen and thawed three consecutive times (liquid nitrogen and room temperature). The cell suspension was centrifuged at $1000 \mathrm{~g}$ for $10 \mathrm{~min}$ and then the supernatant was placed in sample wells with a Zip-Zone applicator (Helena Laboratories B, Texas) and transferred to a cellulose acetate membrane for electrophoresing.

Sterility tests - Cell cultures were periodically checked for sterility, taking two drops of concentrated cells in culture medium and transferring them to tubes containing heart-brain broth infusion or Sabouraud medium. The broth was incubated at $36^{\circ} \mathrm{C}$ for one week and the medium at room temperature for 15 days. Testing for mycoplasma was carried out by the cytologic method, staining with the fluorescent dye Hoeschst-33258 (Chen 1977, Cahoon et al. 1978, Oro 1984).

Cryopreservation - For freezing and cryopreservation, monolayers $80 \%$ confluent were detached and the cells were adjusted to $5 \times 10^{6} / \mathrm{ml}$ with fresh medium containing $20 \%$ fetal bovine serum and $10 \%$ DMSO. The suspension was dispersed into sterile cryotubes and refrigerated at $5^{\circ} \mathrm{C}$, frozen overnight at $-70^{\circ} \mathrm{C}$, and the placed in liquid nitrogen for permanent storage (Hsu et al. 1972, Braude et al. 1986, Léry \& Fédière 1990).

\section{RESULTS}

Cell line - A record of passage for 90 times is shown in Fig. 1. The cell line was designated LSBAA695BB. The primary and early subcultures showed slow growth. The estimated population doubling time was about $24 \mathrm{hr}$. The growth rate gradually increased and became constant after 15 passages. The culture developed a monolayer of firmly attached cells to the flask surface. The initial cells have remained from the embryonic tissue explants were maintained in MK/VP12 medium, with variations in the FBS concentration; beginning from the 10th passage, the FBS was reduced gradually from 20 to $15 \%$ and finally to $10 \%$ after the 40 th passage. Cell cultures were also adapted to the MM/ VP12 medium (Varma \& Pudney 1969) from passage 25 level onward. The $\mathrm{pH}$ range of the medium was 6.8 to 7.0 and the optimum incubation temperature for cells was $28^{\circ} \mathrm{C}$. $\mathrm{A} \mathrm{CO}_{2}$ atmosphere was not required. The viability of frozen cells was shown after the second week and also after six months of storage in liquid nitrogen. There was no evidence of cell contamination with mycoplasma, bacteria or fungi. Microsporidia contamination of transovarial transmission was controlled with $6.0 \mathrm{mg} / \mathrm{ml}$ of albendazole. When the cell cultures were exposed to the drug for up to 17 subcultures during a twomonth period, the parasite was eradicated completely. After drug removal the cell cultures were not reinfected and they have remained microsporidia free. Little control of the parasite was observed at $3.0 \mathrm{mg} / \mathrm{ml}$ albendazole, while at $9.0 \mathrm{mg} / \mathrm{ml}$, an infection decrease was observed together with a cell growth reduction, and marked citophatic effect, at four weeks of treatment. Embryonic tissues explanted in albendazole-free medium, showed a high parasite infection by the second week after initiation, together with a high spore population density, and a low cell growth, preventing the formation of a cell monolayer. 
Characteristics - The majority of cells had a fibroblastic-type morphology (Fig. 2). The number of diploid chromosomes in metaphase was predominantly $6(2 \mathrm{n}=6)($ Fig. 3A); tetraploidia were registered in a smaller proportion. Using the $\mathrm{C}$ banding technique, it was possible to precisely identify centromeric regions (Fig. 4).

Isozymatic patterns - The isozymatic phenotypes were one band each for the four systems ana-

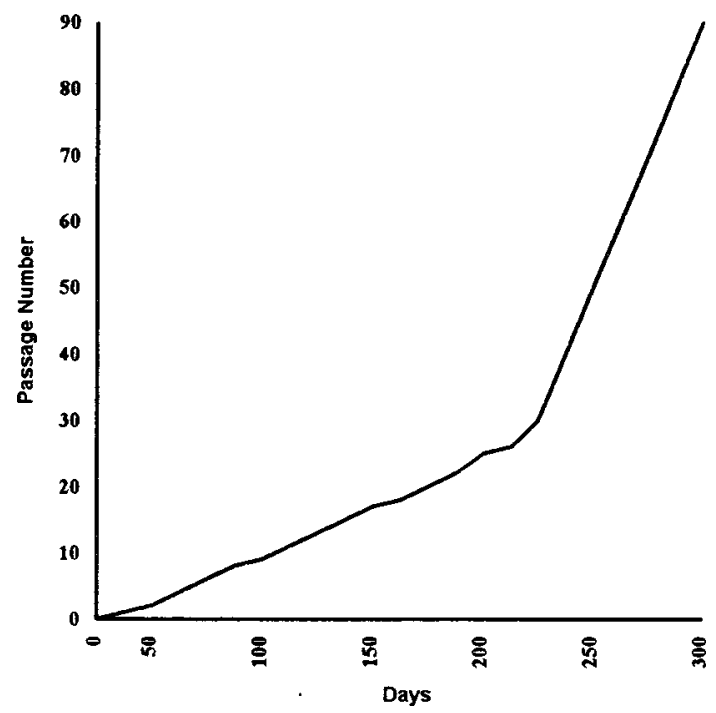

Fig. 1: number of developed passages of the cultured cells within time intervals.

A

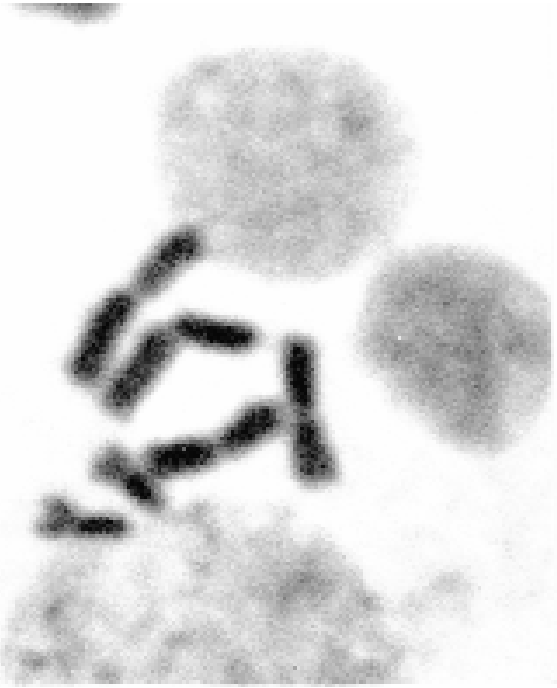

lyzed (PGI, PGM, MPI, 6-PGDH). These results coincided with those obtained from An. albimanus pupae and adult samples simultaneously analyzed with the cell cultures. The average values of relative mobilities of each of the isozymatic systems is shown in Table. They correspond to the present cell line in relation with C6/36 clone and the $A e$. taeniorhynchus cell line. Diagrams of the isozymatic patterns for each of the different systems of cell line can be observed in Fig. 5.

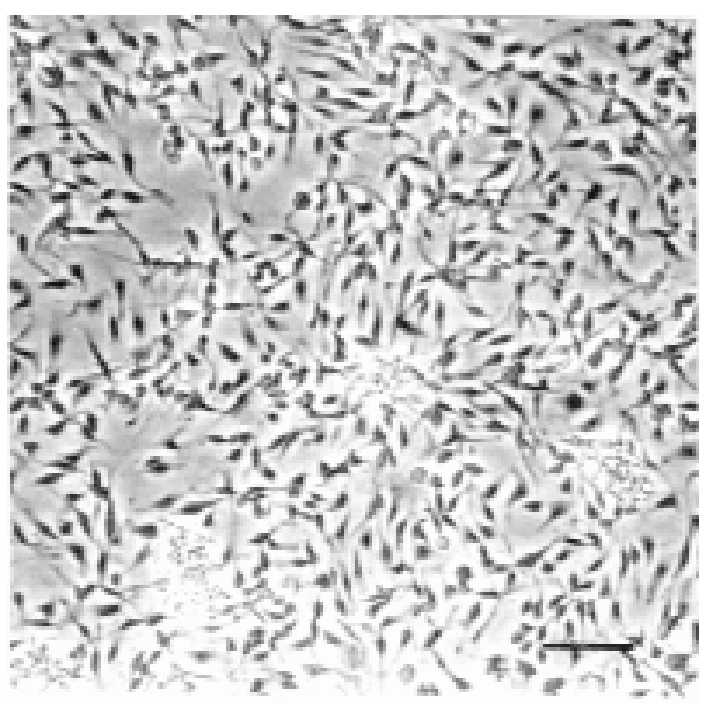

Fig. 2: predominant cell type in the LSB-AA695BB cell line, with fibroblastic cells. Bar=200 mm.

B

Fig. 3: giemsa-staining metaphase chromosome preparations from LSB-AA695BB cell line showing: A. diploid chromosome complement; B. aneuploid chromosome complement. 


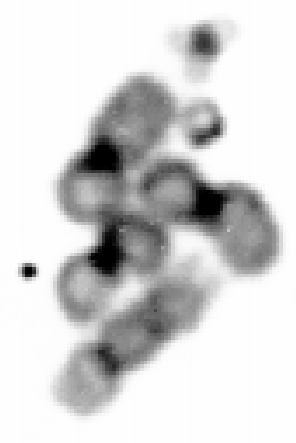

Fig. 4: metaphase karyotype from LSB-AA695BB cell line showing centromeric bands.

TABLE

Comparison of the relative isozymatic mobilities of three mosquito cell line

\begin{tabular}{llllr}
\hline \multirow{2}{*}{ Cell lines } & \multicolumn{4}{c}{ Isozymes } \\
\cline { 2 - 5 } & PGI & PGM & MPI & 6-PGDH \\
\hline LSB-AA695BB & 115.92 & 87.1 & 63.23 & 120.05 \\
Aedes taeniorhynchus & 104.6 & 74.65 & 51.66 & 94.11 \\
& \multicolumn{4}{c}{79.77} \\
C6/36
\end{tabular}

$a$ : isozymatic mobilities were recorded relative to the $\mathrm{C} 6 / 36$ isozyme patterns.

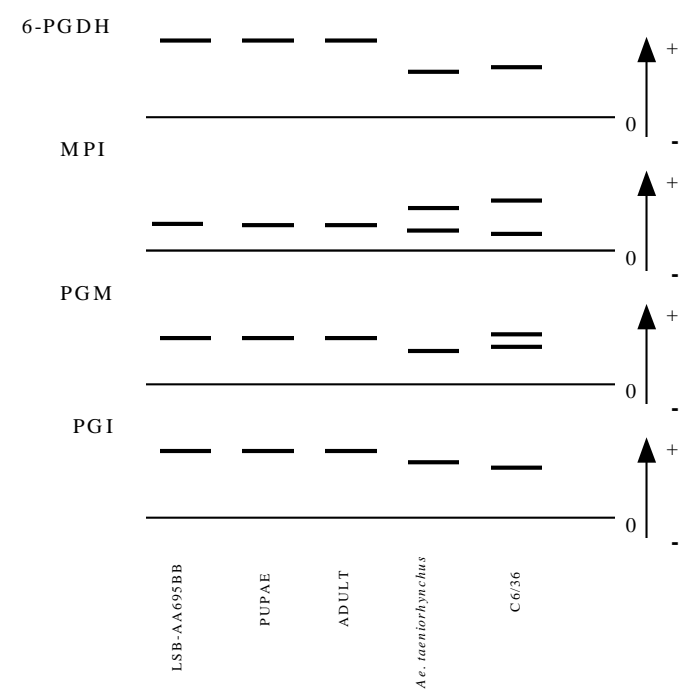

Fig. 5: diagrammatic representation and comparison of the isozymatic patterns from four systems.

\section{DISCUSSION}

The effective antimicrosporidial activity of albendazole, here reported, coincided with previous observations (Haque et al. 1993, Ditrich et al. 1994, Weiss et al. 1994). However, in those studies albendazole was used to test the in vitro antimicrosporidial activity on induced infections, while in the present report, the drug was used to control and eliminate natural infections against microsporidia of transovarial transmission, which were explanted from infected embryos. This antimicrosporidial treatment was necessary to develop a continuous cell line. It was also possible to isolate and maintain in vitro microsporidia of transovarial transmission, with the present technique of cell cultures, without the drug.

The An. stephensis and An. gambiae cell culture were initiated with recently eclosionated larvae; these were cut into fragments and submitted to enzymatic treatments. In the present cell line, primary cell cultures were obtained from embryonated eggs in a relatively short time; the first successful subculture was made after six weeks.

Primary cell growth pattern and morphology coincided with the description by Bello et al. (1995) for their species; except that the first successful subculture of the former was obtained after only two weeks. The slower growth of the present culture may have been due to the presence of parasites, the effect of the antimicrosporidial drug, and/ or because of the frequent medium changes necessary to dilute the free spores.

The cell morphology of the present line was mostly of the fibroblast-type, with characteristics similar to those described for the An. stephensis var. mysorensis cell culture (Pudney \& Varma 1971) but different from that reported for $A n$. gambiae (Marhoul \& Pudney 1972) and An. stephensis (Schneider 1969), which were predominantly epithelioid.

The diploid number of chromosomes for the cell line is $2 n=6$; this coincided with the number established for most Anopheles with the exception of the Chagasia genus, whose chromosomatic complement was of 4 pairs $(2 n=8)$ (Clements 1992).

In cultures exposed to albendazole for a relatively prolonged time ( 3 months), it was noticed that, many of metaphases showed dispersed chromosomes with a tendency toward aneuploids (Fig. 3B). Structural type chromosomic aberrations were also noted, most frequently the duplication of short arms in one of the chromosomes of pair 2. However, after removal of the drug and upon subculturing up to 30 passages, the cytogenetic analysis showed normal cells, mostly diploid metaphases. 


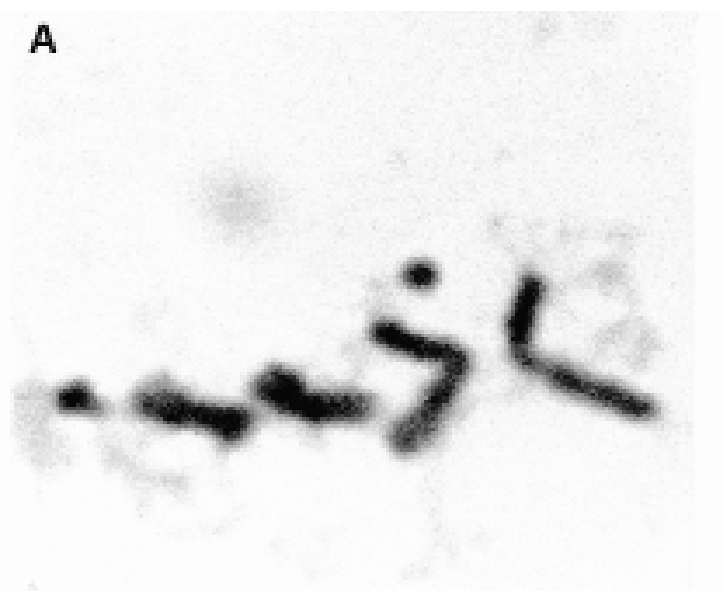

B

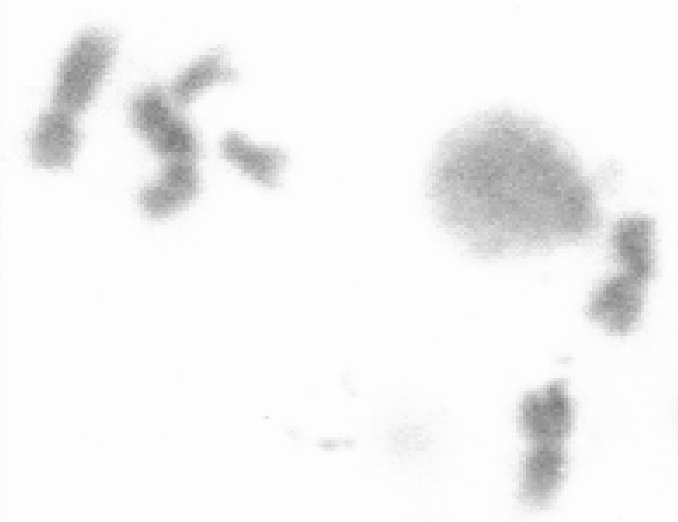

Fig. 6: metaphase karyotypes from LSB-AA695BB cell line A: male; B: female.

In the karyotype, pair 1 is the smaller, heteromorphic sexual chromosome, this description is similar to that reported for somatic chromosomes obtained from brain and gonad cells of $A n$. albimanus as reported by Hobbs (1962). In the female XX pair and the male XY (Fig. 6), the X chromosome is acrocentric whereas the $\mathrm{Y}$ is smaller and of irregular shape; as a general feature, At metaphase, the majority $(90 \%)$ of the cells were of the female XX karyotype; this distribution is probably a random one and not related to adaptive changes. When hundreds of embryonic eggs are observed, the sexual ratio is expected to be in similar proportions, however, it is possible that this ratio may deviate in some years. Braude-Zolotarjova et al. (1986), observed that in eggs cultures of Drosophila virilis cells observed for six years. Female XX karyotype cells were predominant the first year; later, the male karyotype increased and by passages 120 , five years later, female cells were completely replaced by cells with male XY karyotype.

The isozymatic phenotypes of this cell line were identical with those obtained from An. albimanus pupae and adult samples, which indicates that cells in the cultures were representative of the original species. However, when isozymatic patterns of this cell line were compared with zymograms of $A e$. taeniorhynchus cells and the C6/36 clone, a characteristic and different isozymatic profiles were observed for each of above mentioned lines.

\section{ACKNOWLEDGEMENTS}

To Dr RB Tesh, Research Scientist, University of Texas, Department of Pathology, Medical Branch, for his valuable comments and for reading the original manuscript.

\section{REFERENCES}

Bello GFJ, Boshell J, Rey G, Morales A, Olano VA 1995. Initiation of primary cell cultures from embryos of the mosquitoes Anopheles albimanus and Aedes taeniorhynchus (Diptera: Culicidae). Mem Inst Oswaldo Cruz, 90: 547-551.

Braude-Zolotarjova T, Karkpakov VT, Schuppe NG 1986. Male diploid embryonic cell line of Drosophila virilis. In Vitro 22: 481-484.

Brown JE, Knudson DK 1980. Characterization of invertebrate cell lines. III. Isozyme analyses employing cellulose-acetate electrophoresis. In Vitro 16 : 829-833.

Buckley SM 1976. Arboviruses and Toxoplasma gondii in Diptera cell lines, p. 201-203. In K Maramorosch. Invertebrate tissue culture, research applications. New York and London: Academic Press.

Cahoon BE, Hardy JL, Reeves WC 1978. Initiation and characterization of a diploid cell line from larval tissues of Aedes dorsalis (Meigen). In Vitro 14: 255260.

Chen TR 1977. In situ detection of Mycoplasma contamination in cell culture by fluorescent Hoeschst33258 stain. Exp Cell Res 104: 255-262.

Clements AN 1992. The biology of mosquitoes. Development, nutrition and reproduction. Vol 1. Chapman \& Hall, London, 509 pp.

Ditrich O, Kucerova Z, Koudela B 1994. In vitro sensitivity of Encephalitozoon cuniculi and E. hellem to albendazole. J Euk Microbiol 41: 37S.

Grace TDC 1982. Development of insect cell culture, p.1-8. In K Maramorosch \& J Matsuhashi (eds). Invertebrate cell culture, applications. Academic Press, New York.

Haque MA, Hollister WS, Willcox A, Canning EU 1993. The antimicrosporidial activity of albendazole. $J$ Invertebr Pathol 62: 171-177. 
Hink WF 1980. The 1979 compilation of invertebrate cell line and culture media, p. 553-558. In E Kurstak, $\mathrm{K}$ Maramorosch \& A Dubendorfer (eds). Invertebrate systems in vitro. Elsevier, North-Holland Biochemical Press, Amsterdam.

Hobbs JH 1962. Cytogenetics of Anopheles albimanus (Diptera: Culicidae). Ann Ent Soc Amer 55: 245-251.

Hsu SH, Li SY, Cross JH 1972. A cell line derived from ovarian tissue of Culex tritaeniorhynchus summorosus Dyar. J Med Ent 9: 86-91.

Igarashi AI 1978. Isolation of a Singh's Aedes albopictus cell clone sensitive to dengue and chikungunya viruses. J Gen Virol 40: 531-544.

Léry X, Fédière G 1990. A new serum free medium for lepidopteran cell culture. J Invertebr Pathol 55: 342349.

Maramorosch K 1980. Aplications of invertebrate tissue culture to the health and economy of developing nations, p. 579-585. In E Kurtak, K Maramorosch \& A Dubendorfer (eds). Invertebrate systems in vitro. Elsevier, North-Holland Biomedical Press, Amsterdam.

Maramorosch K 1987. Biotechnology in invertebrate pathology and cell culture. Academic Press, San Diego, 511pp.

Marchi A, Mezzanote R, Ferruci L 1980. Characterization of the chromosome in Anopheles stephensi (Liston, 1901) by Q, G and C banding. Cytologia 45: 549-553.

Marhoul Z, Pudney M 1972. A mosquito cell line (Mos.55) from Anopheles gambiae larvae. Trans $R$ Soc Trop Med Hyg 66: 183.

Mitsuahashi J 1981. Establishment and some characteristics of a continuous cell line derived from fat body of the cabbage armyworm (Lepidoptera, Noctuidae). Dev Growth Difter 23: 63-72.

Mitsuahashi J 1983. A continuous cell line derived from fat bodies of the common armyworm, Leucamia separata (Lepidoptera: Noctuidae). Appl Ent Zool 18: 533-539.

Motara MA, Rai KS 1977. Chromosomal differentiation in two species of Aedes and their hybrids revealed by Giemsa C-banding. Chromosoma (Berl.) 64: 125-132.

Oro G 1984. Establishment of a mosquito cell line from Haemagogus equinus larvae. In Vitro 20: 153-156.

Pudney M, Varma MGR 1971. Anopheles stephensi var. mysorensis: Establishment of a larval cell line (Mos.43). Exp Parasitol 29: 7-12.

Schneider I 1969. Establishment of three diploid cell line of Anopheles stephensi (Diptera: Culicidae). J Cell Biol 42: 603-606.

Schneider I 1987. Preparation and maintenance of arthropod cell culture: Diptera, with emphasis on mosquitoes, p. 25. In CE Yunker. Arboviruses in artropod cells in vitro, Vol 1. CRC, Boca Raton, FL.

Varma MGR, Pudney M 1969. The growth and serial passage of cell line from Aedes aegypti $(\mathrm{L})$ larvae in different media. J Med Entomol 6: 432-439.

Vaughn JL 1976. The production of viruses for insect control in large scale cultures of insect cells, p. 295303. In K Maramorosch. Invertebrate tissue culture, research applications, New York and London, Academic Press.

Weiss LM, Michalakakis E, Coyle CM, Tanowitz HB 1994. The in vitro activity of albendazole against Encephalitozoon cuniculi. J Euk Microbiol 41: 65S. 